\title{
Treble Damage Actions for Violations of Section 7 of the Clayton Act
}

The persistent reluctance of the judiciary to allow private plaintiffs to maintain treble damage actions under section 4 of the Clayton Act ${ }^{1}$ to enforce the section $7^{2}$ prohibition on potentially ${ }^{3}$ anticompetitive mergers has dissolved dramatically in recent years. This change in attitude is due primarily to a rejection of the earlier view that since a section 7 violation occurs only at the moment the potentially anticompetitive merger is consummated, before private parties are injured, ${ }^{4}$ the private plaintiff is unable to satisfy the section 4 requirement of injury "by reason of" a section 7 violation.

Section 4 of the Glayton Act authorizes treble damage actions for injuries due to violation of any of the antitrust laws listed in section 1 of the Glayton Act. ${ }^{5}$ While section 7 is included in this listing, some courts feared that private actions based on only potentially anticompetitive mergers might raise the specter of speculative damages. ${ }^{6}$ This fear

115 U.S.C. \& 15 (1964). The statute provides:

Any person who shall be injured in his business or property by reason of anything forbidden in the antitrust laws may sue therefore ... and shall recover threefold the damages by him sustained, and the cost of suit, including a reasonable attorney's fee.

215 U.S.C. $\$ 18$ (1964). The statute provides:

No corporation engaged in commerce shall acquire, directly or indirectly, the whole or any part of the stock ... or any part of the assets of another corporation engaged also in commerce, where in any line of commerce in any section of the country, the effect of such acquisition may be substantially to lessen competition, or to tend to create a monopoly.

3 This differs from most other antitrust laws such as $\$ \S 1$ and 2 of the Sherman Act, 15 U.S.C. $\S \S 1,2$ (1964), which require a showing of actual restraint in the form of monopolization or specific intent to monopolize. See note 10 infra for statutes similar to $\$ 7$.

4 E.g., Bailey's Bakery, Ltd. v. Continental Baking Co., 235 F. Supp. 705, 716-17 (D. Hawaii 1964), aff'd, 401 F.2d 182 (9th Cir. 1968), cert. denied, 393 U.S. 1086 (1969): "The prohibitory sanctions of Clayton $\S 7$ are triggered to explode by and at the moment of acquisition. That, after the moment of acquisition, subsequent business practices do injure competitors in that market does not, because of those subsequent injurious acts, give rise to a claim for treble damages under Clayton § 7."

515 U.S.C. \& 12 (1964).

6 E.g., Bailey's Bakery, Ltd. v. Continental Baking Co., 235 F. Supp. 705, 716-17 (D. Hawaii 1964): "Since Clayton $\S 7$ is concerned with the future monopolistic and restraining tendencies of corporate acquisition, i.e., probable (and hence not certain) future restraints on commerce, any damages claimed for prospective restraint of trade would be purely speculative ... and a plaintiff cannot recover money damages for anticipated but unimplemented acts of restraint which may invade its interests." This "potential" character of the $\S 7$ test presents no problem in government actions against proposed mergers 
led the judiciary to prohibit $\S 4-\S 7$ actions not only in those cases where injury had not occurred, but even where actual injury of a nonspeculative nature was already present. ${ }^{8}$ The courts could not envision the section 7 violation-the act of merger, as opposed to the subsequent acts of the merged firm-ever causing injury.

In the first case to recognize the $\S 4-\S 7$ right of action, Ames $v$. Bostitch, Inc., ${ }^{9}$ the injury was easily attributable to the act of merger. The plaintiff's dealership was terminated when his supplier was acquired by a competing dealer. Since the acquiring company was a competitor of the plaintiff, the merger inevitably led to the termination and was thus deemed to be the cause of the injury. Later decisions have broadened the causation concept still further by permitting private section 7 actions for injuries due to subsequent conduct made possible by the illegal merger. ${ }^{10}$ Thus, although not yet approved expressly by

because the government seeks either injunctive relief or divestiture rather than compensation for injuries.

7 Several cases have dismissed the plaintiff's $\$ 4-\S 7$ action because of a failure to prove the fact of injury: Blaski v. Inland Steel Co., 271 F.2d 853 (7th Cir. 1959); Bender v. Hearst Corp., 263 F.2d 360 (2d Cir. 1959); McKeon Constr. Co. v. McClatchy News. papers, 1970 CCH Trade Cas. I 73,212 (N.D. Cal. 1969); Rayco Mfg. Co. v. Dunn, 234 F. Supp. 593 (N.D. Ill. 1964); New Grant-Patten Milk Co. v. Happy Valley Farms, Inc., 222 F. Supp. 319 (E.D. Tenn. 1963).

8 Highland Supply Corp. v. Reynolds Metals Co., 245 F. Supp. 510, 512-13 (E.D. Mo. 1965): "The problem arises because a plaintiff cannot allege that he has been injured solely by a merger or acquisition which has potential prohibited effects. Instead he must allege that he has been injured by such a merger and subsequent activities." The other cases that deny the existence of the $\S 4-\S 7$ action are: Highland Supply Corp. v. Reynolds Metals Co., 327 F.2d 725 (8th Cir. 1964); Burkhead v. Phillips Petroleum Co., 308 F. Supp. 120 (N.D. Cal. 1970); Dairy Foods, Inc. v. Farmers Co-op Creamery, 298 F. Supp. 774 (D. Minn. 1969); Gottesman v. General Motors Corp., 279 F. Supp. 361 (S.D.N.Y. 1967), rev'd and remanded, 414 F.2d 956 (2d Cir. 1969); Bailey's Bakery, Ltd. v. Continental Baking Co., 235 F. Supp. 705 (D. Hawaii 1964).

0240 F. Supp. 521 (S.D.N.Y. 1965).

10 Gottesman v. General Motors Corp., 414 F.2d 956, 961 (2d Cir. 1969): "[x]f the threat [of potential restraints] ripens into reality we do not see why there can never be a private cause of action for damages. If $\S 7$ is designed to prevent acquisitions that 'may' or 'tend to' cause specified harm, such an acquisition may either itself directly bring about the harm or make possible acts that do." See Kirihara v. Bendix Corp., 306 F. Supp. 72 (D. Hawaii 1969), for extensive discussion of the existence of the $\S 4-\S 7$ action.

If properly applied, a broad causation theory is justified by three considerations: First, private damage actions are available to enforce related statutes phrased in terms of "potential" restraint. $\$ 2$ of the Clayton Act (Robinson-Patman Antidiscrimination Act), I5 U.S.C. $\S 13($ a) (1964), and $\$ 3$ of the Robinson-Patman Act, 15 U.S.C. $\$ 14$ (1964), prohibit conduct which "may substantially lessen competition." \$ 2 can clearly be enforced by a private action, Utah Pie Co. v. Continental Baking Co., 386 U.S. 685 (1967), although $\$ 3$ will support a private action only where a \$ 2 violation is also present. Nashville Milk Co. v. Carnation Co., 355 U.S. 373 (1958). But cf. Moore v. Mead's Fine Bread Co., 348 U.S. 115 (1954). The explanation for this apparent inconsistency is that while $\S 2$ of the Robinson-Patman Act amended $\$ 2$ of the Clayton Act and thus is included in the antitrust laws (as defined by $\S 1$ of the Clayton Act) that can be enforced under $\S 4, \& 8$ is not 
the Supreme Court, ${ }^{11}$ the present trend, which rejects the narrow causal view and recognizes the existence of the treble damage action for violation of section 7, seems firmly entrenched in the lower federal courts. ${ }^{12}$ However, this trend raises difficult questions of enforcement policy stemming from the subtle nature of the section 7 prohibition. The statute does not proscribe all economically injurious acts of illegally merged firms; it prohibits only acts of an anticompetitive nature. ${ }^{13}$ Moreover, although the anti-merger statute was intended to prevent "minute accretions of power,"14 it is not a legislative judgment that all mergers are bad. ${ }^{15}$ Indeed, mergers that do not unduly impede competition may have beneficial economic effects such as the realization of economies of scale or the elimination of inefficient management. ${ }^{16}$ Thus, unless caution is exercised, the uncertainty in distinguishing legal from illegal mergers and in isolating the anticompetitive acts of illegally merged firms, when coupled with the punitive nature of the treble damage action, could unnecessarily deter desirable mergers.

one of those laws. Secondly, since a private party can get injunctive relief for a threatened irreparable injury because of an illegal merger, he should also be entitled to money damages if the threatened injury is consummated. 15 U.S.C. $\$ 26$ (1964). American Crystal Sugar Co. v. Cuban-American Co., 259 F.2d 524 (2d Cir. 1958). Thirdly, the Supreme Court has admonished against restrictive interpretations of $\S 4$. E.g., Radovich v. National Football League, 352 U.S. 445, $453-54$ (1957): “Congress has, by legislative fiat, determined that such prohibited activities are injurious to the public and has provided sanctions allowing private enforcement of the antitrust laws by an aggrieved party .... In the face of such a policy this Court should not add requirements to burden the private litigant beyond what is specifically set forth by Congress in those laws."

11 In Federal Trade Comm'n v. Dean Foods Co., 384 U.S. 597 (1966), the Court implied that injunctive relief is the only appropriate weapon of a private party to enforce $₹ 7$. But cf. Minnesota Mining \& Mfg. Co. v. New Jersey Wood Finishing Co., 381 U.S. 311 (1965) (implying the existence of a $\$ 4-\S 7$ action because the question was whether the four-year statute of limitations was tolled in a case based in part on a $\S 7$ cause of action).

12 Recognizing the $\S 4-\S 7$ action: Gottesman v. General Motors Corp., 414 F.2d 956 (2d Cir. 1969), rev'g 279 F. Supp. 361 (S.D.N.Y. 1967), cert. denied, 379 U.S. 882 (1964); Daily v. Quality School Plan, Inc., 380 F.2d 484 (5th Cir. 1967), decision on remand aff'd, 427 F.2d 1080 (5th Cir. 1970); Metric Hosiery Co. v. Spartans Indus., Inc., 50 F.R.D. 50 (S.D.N.Y. 1970); Weinstein Inv. Co. v. Hearst Corp., 310 F. Supp. 390 (N.D. Cal. 1969), rev'g on rehearing 303 F. Supp. 646 (N.D. Cal. 1969); Kirihara v. Bendix Corp., 306 F. Supp. 72 (D. Hawaii 1969); Metropolitan Liquor Co. v. Heublein, Inc., 305 F. Supp. 946 (E.D. Wis. 1969); Bowl America, Inc. v. Fair Lanes, Inc., 299 F. Supp. 1080 (D. Md. 1969); Ames v. Bostitch, Inc., 240 F. Supp. 521 (S.D.N.Y. 1965).

13 See notes $47-49$ infra.

14 The Committee Reports on the Celler-Kefauver Amendment to $\S 7$ of the Clayton Act in 1950 (64 Stat. 1125) indicate that the objective was to prevent accretions of power that are "individually so minute as to make it difficult to use the Sherman Act test against them." S. REP. No. 1775, 81st Cong., 2d Sess. 5 (1950). See H.R. REP. No. 1191, 81st Cong., Ist Sess. 3 (1949); Brown Shoe Co. v. United States, 370 U.S. 294, 323 n.39 (1962).

15 See Kirihara v. Bendix Corp., 306 F. Supp. 72, 85 (D. Hawaii 1969),

16 See, e.g., Geneen, Concepts of a Conglomerate or a Multi-Market Company: A Businessman's View, 39 A.B.A. AnTITrust L.J. 1, 4 (1969). J.K. Galbrarth, The NEw INdustrial STATE 194 (1968). 
This comment focuses on the problem of defining the standards of standing to recover that will permit the maximum possible enforcement of section 7 while still shielding "good" mergers from liability under section 4.

\section{The General Gharacteristics of Section 4}

To maintain a treble damage action under section 4 of the Clayton Act, a private plaintiff must establish a violation of the antitrust laws, ${ }^{17}$ a pecuniary injury, ${ }^{18}$ to business or property, ${ }^{19}$ and compliance with the statute of limitations. ${ }^{20}$ Additionally, the plaintiff must prove the existence of a causal connection between the violation and the injury. ${ }^{21}$ Some courts use such familiar labels as "proximate" or "primary" to express the degree of causation required. ${ }^{22}$ Another line of cases expresses the causation requirement in terms of a dual "target area" test"23 whereby the plaintiff must show first that he is a member of the sector of the economy in which the violation lessens competition,,$^{24}$ and second that the harm was of the type that the particular substantive prohibition was designed to prevent. ${ }^{25}$

The causation question, under both tests, has been transformed in

1715 U.S.C. $\S 15$ (1964). See note I supra for text of statute.

18 Id. Although $\S 7$ is phrased in terms of "potential" restraints thus prohibiting conduct that has not actually resulted in a restraint of competition, this does not mean that a plaintiff can succeed in a $\S 4$ action by showing only a potential injury. While injunctive relief might be available under $\S 16$ of the Clayton Act in such a case, there must be actual damage to justify recovery under $\S 4$.

19 Id. See, e.g., Delaware Valley Marine Supply Co. v. American Tobacco Co., 184 F. Supp. 440, 443 (E.D. Pa. 1960), aff'd, 297 F.2d 199 (3d Cir. 1961), cert. denied, 369 U.S. 839 (1962).

20 I5 U.S.C. $\$ 15(b)$ (1964). See Stein, Section 7 of the Clayton Act as a Basis for the Treble Damage Action: When May the Private Litigant Bring His Suit? 56 CALrf. L. REv. 968 (1968).

21 E.g., Burnham Chem. Co. v. Borax Consol., 170 F.2d 569, 571 (9th Cir. 1948), cert. denied, 336 U.S. 924 (1949) (discussing the necessity of "injury" in a $\$ 4$ action). See generally Note, Standing to Sue for Treble Damages Under Section 4 of the Clayton Act, 64 Colum. L. REv. 570 (1964).

22 Brewer Sewing Supplies Co. v. Fritz Gegouf, Ltd., 1970 CCH Trade Cas. I 73,139 (N.D. Ill. 1970). The first case requiring a showing that the injury had to be direct and not derivative was Loeb v. Eastman Kodak Co., 183 F. 704 (3d Cir. 1910).

23 E.g., Harman v. Valley Nat'l Bank, 339 F.2d 564, 567 (9th Cir. 1964); Productive Inventions, Inc. v. Trico Prods. Corp., 224 F.2d 678, 679 (2d Cir. 1955), cert. denied, 350 U.S. 936 (1956); Karseal Corp. v. Richfield Oil Corp., 221 F.2d 358, 362-63 (9th Cir. 1955).

24 Conference of Studio Unions v. Loew's, Inc., 193 F.2d 51, 54-55 (9th Cir. 1951), cert. denied, 342 U.S. 919 (1952): "[A] plaintiff must show more than that one purpose of the conspiracy was a restraint of trade and that an act has been committed that harms him. He must show that he is within that area of the economy which is endangered by a breakdown of competitive conditions in a particular industry. Otherwise he is not injured 'by reason of' anything forbidden in the antitrust laws."

25 Pollock, Standing to Sue, Remoteness of Injury, and the Passing-on Doctrine, 32 A.B.A. ANTrtrust L.J. 5, 19 (1966). 
many cases into a question of standing which is generally resolved by the court at the outset of litigation on a motion to dismiss. ${ }^{26}$ This transformation, however, has not eliminated many of the complexities of the causation problem. ${ }^{27}$ For example, the standing of plaintiffs who are not in direct relations with the antitrust violator, but who deal with the party receiving the primary impact of the violation, is still unsettled. ${ }^{28}$ And, despite the Supreme Court's admonition against too restrictive a reading of section 4,29 its disapproval of the imposition of burdens not created by Congress, ${ }^{30}$ and its own liberal interpretations of standing requirements in antitrust cases, ${ }^{31}$ some courts have formulated inflexible standing rules requiring that the plaintiff be in privity of contract or have direct relations with the violator. ${ }^{32}$

26 E.g., Billy Baxter, Inc. v. Coca Cola Co., 431 F.2d 183 (2d Cir. 1970); Sanitary Milk Producers v. Bergjans Farm Dairy, Inc., 368 F.2d 679 (8th Cir. 1966). For example, in Volasco Prods. v. Lloyd A. Fry Roofing Co., 308 F.2d 383, 395 (6th Cir. 1962), cert. denied, 372 U.S. 907 (1963), the court said: "It is well established in the law that a supplier is too remote and too far removed from the direct injury to recover damages resulting from violation of the anti-trust laws directed against the supplier's customer." As a result, whenever a supplier brings an action alleging an antitrust violation by the defendant against his customer he would likely have to overcome a challenge to his standing to sue. See also Snow Crest Beverages, Inc. v. Recipe Foods, Inc., 147 F. Supp. 907 (D. Mass. 1956); Billy Baxter, Inc. v. Coca Cola Co., 431 F.2d 183 (2d Cir. 1970) (denying standing to a franchisor to bring an antitrust action against his franchisee). But see Sanitary Milk Producers v. Bergjans Farm Dairy, Inc., 368 F.2d 679 (8th Cir. 1966) (The court elects to follow the liberal Karseal case rather than Snow Crest and allows standing to a plaintiff who is in the position of a supplier. In both Karseal and Sanitary, however, the plaintiffs sold all of their products through the injured customer.). In Mulvey v. Samuel Goldwyn Prods., Inc., $1970 \mathrm{CCH}$ Trade Cas. I 73,361, at 89,450 (9th Gir. 1970), the court explained that the language "by reason of" in \$ 4 of the Clayton Act "has been judicially construed to embrace not only the legal causation element, but also the standing concept, which in this setting is a close relative of causation."

27 It has, however, received abundant attention elsewhere. Pollock, supra note 25; Note, supra note 21.

28 Compare Billy Baxter, Inc. v. Coca Cola Co., 431 F.2d 183 (2d Cir. 1970) (a franchisor not allowed standing), and Fields Prods., Inc. v. United Artists Corp., 318 F. Supp. 87 (S.D.N.Y. 1970), aff'd, 432 F.2d 1010 (2d Cir. 1970), with Karseal Corp. v. Richfield Oil Corp., 221 F.2d 358 (9th Cir. 1955) (supplier allowed to sue for violation against his customer), and Mulvey v. Samuel Goldwyn Prods., Inc., $1970 \mathrm{CCH}$ Trade Cas. \ 73,361 (9th Cir. 1970).

29 Radovich v. National Football League, 352 U.S. 445, 453-54 (1957).

30 E.g., Poller v. Columbia Broadcasting Sys., Inc., 368 U.S. 464, 473 (1962); Bigelow v. RKO Radio Pictures, Inc., 327 U.S. 251 (1946).

31 Radiant Burners, Inc. v. People's Gas Light \&. Coke Co., 364 U.S. 656, 660 (1961); Klor's, Inc. v. Broadway-Hale Stores, Inc., 359 U.S. 207, 213 (1959) (violation is not to be tolerated "merely because the victim is just one merchant whose business is so small that his destruction makes little difference to the economy").

32 For example, parties whose injury occurs because another party whom they depend upon was directly injured by an antitrust violation have been barred from maintaining a treble damage action against the violator. E.g., Brewer Sewing Supplies Co. v. Fritz Gegouf, Ltd., $1970 \mathrm{CGH}$ Trade Cas. I 73,139 (N.D. Ill. 1970) (creditor of the party directly injured 
Since the standing rules determine which categories of plaintiffs may challenge an alleged violator's conduct, they play an important role, through the deterrent effect of treble damage actions, in defining the effective scope of those antitrust laws that may be enforced under section 4. As a result, the appropriate enforcement goals of the various substantive prohibitions should be considered in developing causation standards. No uniform causation principle can be formulated to cover all sections of the substantive antitrust laws, for each law regulates different conduct and requires different degrees of proof. For example, sections 1 and 2 of the Sherman $\mathrm{Act}^{33}$ proscribe actual restraint or monopoly or specific intent to monopolize, while section 7 of the Clayton Act prohibits mergers that have only a potential to restrain competition. Thus, the fact that a section 7 violation "admits of a lower standard of proof of the same kind of acts which if carried to their logical result give rise to a Sherman Act violation, must not be overlooked." ${ }^{34}$ The tendency of the courts to formulate mechanical rules of standing applicable to all section 4 cases could thus result in an enforcement policy not related to the goals of the particular substantive provision in question. $^{35}$

Because there have been few $\S 4-\S 7$ cases, the development of standards of standing in such actions is in its incipiency. This lack of precedent provides the courts with an opportunity to avoid the pitfalls of mechanical standing tests so common in other types of section 4 actions. Proper enforcement of section 7 demands that its special characteristics be considered in formulating the scope of recovery for its violation. ${ }^{36}$

barred); United Egg Producers v. Bauer Int'l Corp., 312 F. Supp. 319 (S.D.N.Y. 1970) (consumer not allowed to maintain action for antitrust violation directed against his supplier and thus injuring him); Walder v. Paramount Pub. Corp., 132 F. Supp. 912 (S.D.N.Y. 1955); Gerli v. Silk Ass'n, 36 F.2d 959 (S.D.N.Y. 1929) (employees and officers not allowed action for violation against their employer by another corporation).

3315 U.S.C. $\S \S 1,2$ (1964).

34 Kirihara v. Bendix Corp., 306 F. Supp. 72, 90 (D. Hawaii 1969). See Pollock, supra note 25 , at 19 .

35 Cf. Billy Baxter, Inc. v. Coca Cola Co., 431 F.2d 183, 191 (2d Cir. 1970) (dissenting opinion): "Several courts, however, have resisted the adoption of labelous rules of standingto-sue and have looked to some extent behind the 'indirectness' label in an effort to preserve the basic policy considerations that give the standing-to-sue requirement its viability."

36 Pollock, supra note 25, at 19, recognized that a different standard was necessary for 87 enforcement: "[The] 'target area' principle . . . represents a substantial improvement over the 'direct-indirect' test. Although there may occasionally be disagreement as to who is in the 'target area' of certain types of violations-for example, a Section 7 violation would necessitate a different analysis than an exclusive dealing violation ...." 


\section{STANDARDS FOR RECOVERY IN $§ 4-\S 7$ Actions}

This section examines three divergent judicial approaches to the standing problem in an attempt to ascertain the most appropriate standing rules in a $\S 4-\S 7$ action.

\section{A. An Overboard Approach: Daily v. Quality School Plan, Inc.}

With little thought to the special characteristics of section 7 , the Court of Appeals for the Fifth Circuit, in Daily v. Quality School Plan, Inc. ${ }^{37}$ adopted a rule that would allow recovery by an employee of a magazine subscription sales firm. The court adopted the reasoning of a Sherman Act case propounding a general "directness of injury" causation standard, ${ }^{38}$ and held that the employee could recover if he were able to prove a section 7 violation. ${ }^{39}$

Both the specific characteristics of section 7 and the general nature of section 4 actions militate against acceptance of Daily's non-specialized causation formulation. In terms of section 7, rejection of the Daily test is suggested by the interaction of the "potential" character of the section 7 prohibition with two particular problems in regulating mergers: (1) the difficulty in differentiating bad mergers from good mergers, and (2) the difficulty in determining the specific acts for which those guilty of bad mergers should be answerable in damages. Moreover, the need for specialized standing requirements in $\S 4-\S 7$ actions is reinforced by an additional factor: (3) the deterrent impact of all treble damage actions.

1. Identifying the Illegal Merger. In a $\S 4-\S 7$ action the court is asked to attribute an injury to an allegedly illegal merger. Unless the injury itself indicates the nature of the effect of the merger on competition, the decision as to the legality of the merger must be made by evaluation of independent evidence. ${ }^{40}$

The major element in determining the illegality of the merger in any

37 Daily v. Quality School Plan, Inc., 380 F.2d 484 (5th Cir. 1967).

38 South Carolina Council of Milk Producers, Inc. v. Newton, 360 F.2d 414 (4th Cir. 1966), cert. denied, 385 U.S. 934 (1966). Another case, Weinstein Inv. Co. v. Hearst Corp., 310 F. Supp. 390 (N.D. Cal. 1969), presents a similar situation where the court adopted a non-specialized causation formula although it ultimately rejected the $\S 4-\S 7$ action as a matter of law. The court included within the target area anyone who reasonably could be foreseen to be affected by the antitrust violation. In this case the plaintiff, an employee of a non-competing firm, had only to allege that defendant could have foreseeably realized that his conduct could drive certain firms out of business resulting in loss of employment to a class of persons of which plaintiff is one.

39 After the merger Quality controlled $82 \%$ of the market. Nevertheless, the plaintiff lost at trial and on appeal. Daily v. Quality School Plan, Inc., 427 F.2d 1080 (5th Cir. 1970).

40 E.g., United States v. E.I. duPont de Nemours \& Co., 366 U.S. 316 (1961); United States v. Allis Chalmers Mfg. Co., 1970 CCH Trade Cas. I 73,341 (E.D. Wis. 1970). 
section 7 case is the definition of the "line of commerce" or relevant market in which it is asserted that competition may be lessened. For example, in United States $v$. Allis Chalmers $\mathrm{Mfg}$. Co. ${ }^{41}$ the defendant won because his definition of the relevant market as "mobile outdoor power equipment generally" prevailed over the government's definition of "riding garden tractors and attachments," 42 a smaller market controlled by the defendant. Courts have identified numerous factual criteria thought to indicate the perimeters of the relevant market. ${ }^{43}$ But defining the relevant market remains a complex question fraught with uncertainty, ${ }^{44}$ and the courts are often unable to formulate a reasonably clear, yet economically realistic definition..$^{45}$ Unavoidable errors in defining market perimeters are likely to be compounded by the "potential" nature of section 7, which invites speculation as to the markets in which the merged firm might develop control. ${ }^{46}$ The consequent propensity for error cautions against allowing recovery by private plaintiffs under a broad standing rule such as the one announced in Daily.

2. Identifying the Anticompetitive Acts of Illegally Merged Firms. All mergers are accompanied by economic readjustments which injure a multitude of parties. ${ }^{47}$ Many such adjustments are intended to in-

$411970 \mathrm{CCH}$ Trade Cas. I 73,341 (E.D. Wis. 1970).

42 Id. at 89,351 .

43 See generally Note, The Diversifying Corporation: Section 7 Darwinism and the Elusive but Essential Tests of the Marketplace, 44 Sr. JoHN's L. REv. 677 (1970), for discussion of $\S 7$ enforcement by government actions. Brown Shoe Co. v. United States, 370 U.S. 294 (1962), was the first definitive interpretation of $\S 7$. The Court recognized that no one test of relevant market would suffice. Taking the pragmatic, factual approach, every case must be examined to identify various factors that courts have held indicative of relevant market, such as interchangeability of use of the product with other products, cross elasticity of demand, and whether sold to distinct classes of customers.

44 Lewyn \& Mann, Some Thoughts on Policy and Enforcement of Section 7 of the Clayton Act, 50 A.B.A.J. 154, 156-57 (1964).

45 Adler, Merger Rules and Supreme Court Economics, 36 A.B.A. ANTrTrusr L.J. 4 (1967); P. Asch, Economic Theory and the ANTItrust Dilemana 324-25 (1970):

The main criticism of public merger policy is that it has become an indiscriminate weapon against corporate bigness, used to strike down large combinations without considering the possibility that large size be economically justified. The Supreme Court's implicit answer to this criticism is that it is not concerned with economic justifications-nor with any benefit-versus-cost approach-but rather is concerned with competition, defined in a particular structural fashion. Here the economist may argue that the Court's definition of competition is inadequate, but the Court's (again implicit) response is: that is what Congress intended.

40 In Kirihara v. Bendix Corp., 306 F. Supp. 72, 90 (D. Hawaii 1969), the court stated: "Under $\S 7$, as amended, it is unnecessary 'to show that as a result of a merger the acquiring firm has already obtained such a degree of control that it possessed the power to destroy or exclude competitors or fix prices.' " (Citing H.R. REP. No. 1191, 81st Cong., 1st Sess. 8 (1949). Emphasis added by court.)

47 Kirihara v. Bendix Corp., 306 F. Supp. 72, 85 (D. Hawaii 1969): "It is axiomatic that every agreement concerning trade, ergo, every merger, whether it be horizontal, 
troduce beneficial production efficiencies. For instance, a distributor may be terminated because there are duplicate distribution systems after the merger, or, as in Daily, an employee may be dismissed because the new combined enterprise has no need for his services. Such injuries are economically justified and were not intended to be proscribed by the statute. ${ }^{48}$ Thus even illegally merged firms should not be liable under $\S 4$ for all their harmful acts, ${ }^{49}$ but only for those acts which reflect their anticompetitive nature. A different rule would result in a greater punishment to the section 7 violator than is justified by the extent of his violation. Isolating the anticompetitive acts of the merged firm is a difficult but essential task, yet it is ignored by the Daily general causation test. The "potential" nature of the section 7 violation, whereby the universe of illegally merged firms includes many which have not engaged in any anticompetitive acts whatsoever, accentuates the importance of formulating a $\S 4-\S 7$ test which seeks to isolate such acts.

3. The Deterrent Impact of Private Actions. When $\S 4-\S 7$ actions are based on prior government cases, their punitive, treble damage nature certainly enhances the deterrent impact of the government proceedings. And even an independent $\S 4-\S 7$ action might well have a greater deterrent impact than a government suit which seeks injunctive relief that is remedial in nature. ${ }^{50}$ Moreover, it is more important for courts to assess the deterrent effect of private actions than that of government actions. The government presumably represents the public interest. Thus, when assessing the desirability of proceeding against

vertical or conglomerate, produces some restraint, some change, and more and more often than not someone is in some way 'injured' by that merger."

48 Recovery for such injuries could appropriately be characterized as a "windfall," Snow Crest Beverages, Inc. v. Recipe Foods, Inc., 147 F. Supp. 907, 909 (D. Mass. 1956) (Wyzanski, J.).

49 In Gottesman v. General Motors Corp., 39 U.S.L.W. 2381 (S.D.N.Y. Jan. 4, 1971), the court held that the private plaintiffs could not use the prior Government judgment that the merger violates $\& 7$ as prima facie evidence of the private injury to the plaintiffs: "Private injury does not necessarily accompany such a policy injury. Indeed, it is possible that a public injury might result from an antitrust violation by a seller while at the same time the buyer was financially benefited." Another reason is suggested by Snow Crest Beverages, Inc. v. Recipe Foods, Inc., 147 F. Supp. 907, 909 (D. Mass. 1956): "In effect, businessmen would be subjected to liabilities of undefinable scope for conduct already subject to drastic private remedies. Courts aware of these considerations have been reluctant to allow those who were not in direct competition with the defendant to have a private action even though as a matter of logic their losses were foreseeable." Contra, Perma Life Mufflers, Inc. v. International Parts Corp., 392 U.S. 134 (1968); Hanover Shoe Co. v. United States Shoe Mach. Corp., 392 U.S. 481 (1968), where the Court, stressing the deterrent value of $\S 4$ actions, subordinated concern about windfalls to the deterrent objective.

50 See, e.g., United States v. Aluminum Co. of America, 148 F.2d 416 (2d Cir. 1945) (equitable relief in the form of dissolution considered a remedy not a penalty). 
particular mergers, it is likely to take cognizance of the deterrent impact of its actions on other mergers which might be of benefit to society. The motivations of private plaintiffs, on the other hand, are pecuniary in nature. ${ }^{51}$ As a result, responsibility for assessing the deterrent impact of $\S 4-\S 7$ actions must be assumed, in the first instance, by the courts who formulate recovery standards. If the degree of uncertainty that prevails in government cases in isolating illegal mergers ${ }^{52}$ were tolerated in $\S 4-\S 7$ actions in isolating such mergers and their anticompetitive effects, the treble damage nature of section 4 might well result in deterrent overkill of beneficial mergers. Thus, in $\S 4-\S 7$ actions a nonspecialized causation formula of the type advocated by Daily is inappropriate. The right of recovery should be restricted to give added assurance that the injuries compensated are only those intended to be prevented by section 7 .

\section{B. A Confining Approach: Ames v. Bostitch, Inc.}

In contrast to the unrestricted approach of the Fifth Circuit in Daily, a district court in Ames v. Bostitch, Inc.53 adopted a confining time-oriented causation requirement. This standard would restrict recovery to plaintiffs whose injury occurred simultaneously with the consummation of the allegedly illegal merger, thus precluding recovery for injuries due to subsequent activity by the merged firm. Although such a narrow standard effectively shields legally merged firms from liability, it seems to grant too much immunity to illegally merged firms. Contrary to the suggestion of one court, ${ }^{54}$ in many situations the subsequent anticompetitive conduct of an illegally merged firm would not necessarily rise to the level of a Sherman Act violation for which treble damages could be recovered.55 Thus, because the time-oriented require-

81 This problem exists in all treble damage actions. Theoretically it is accounted for in the "target area" concept but usually the inquiry into whether the injury was of the type the statute intended to prevent is not made. Text at notes 23-25 supra.

52 See text and note at notes $40-46$ supra.

53240 F. Supp. 521 (S.D.N.Y. 1965). See text at note 9 supra.

54 The court in Bowl America, Inc. v. Fair Lanes, Inc., 299 F. Supp. 1080, 1097 (D. Md. 1969), supplements the time-oriented approach by suggesting that one injured by subsequent conduct is not without a remedy. The court reasons that a private plaintiff injured by subsequent acts of an illegally merged firm in restraint of trade could recover in treble damages under $\S 1$ of the Sherman Act. See Burkhead v. Phillips Petroleum Co., 308 F. Supp. 120 (N.D. Cal. 1970) ( $\$ 4-\S 7$ action can be maintained only at the time of acquisition).

55 The Sherman Act is an inadequate alternative for three reasons: (1) The act which caused the injury, standing alone without the illegality of the merger, might not constitute a violation of the Sherman Act. Bender v. Hearst Corp., I52 F. Supp. 569, 579 (D. Conn. 1957), aff'd on other grounds, 263 F.2d 360 (2d Cir. 1959) (where plaintiff, terminated after a merger, was unable to maintain a $\$ 4-\$ 7$ action as a matter of law and was denied relief 
ment is a mechanical test, an illegally merged firm could avoid treble damage liability altogether by delaying anticompetitive conduct until several months after the date of the merger.

\section{G. An Intermediate Approach: Kirihara v. Bendix Corp.}

One private section 7 case takes a middle position between the general proximate cause standard of Daily and the narrow Ames time-oriented formula. In Kirihara $v$. Bendix Corp.,$^{56}$ the plaintiff, a distributor of Fram oil filters, was terminated after a Bendix-Fram merger because the former Bendix distributor was given the distribution account of the combined business. The district court denied the plaintiff relief because it found him to be of "minimal competitive significance" and because there was no indication that the merger would restrain competition in the Hawaiian oil filter market. The court indicated that some injuries resulting from mergers, even illegal mergers, should be denied a section 4 remedy. ${ }^{57}$

To define the scope of $\S 4-\S 7$ actions the Kirihara court adapted the dual "target area" approach developed in earlier section 4 actions for violations of other sections of the antitrust laws. ${ }^{58}$ The court required, first, that plaintiffs be "one of the components of the competitive infra-structure of the relevant market," and second, that the plaintiff's injury "validate the reasonable probability that a substantial anticompetitive effect upon the viability of competition" will be created by the allegedly illegal acquisition. ${ }^{59}$

1. The Market Component Requirement. The requirement that plaintiffs be components of the relevant market effectively limits the $\S 4-\S 7$ action to competitors or persons suing in the capacity of com-

completely because he could not show that his termination constituted a violation of the Sherman Act: "[]] is apparent that this case would fall within that class of meirgers which have not attained the effects which bring them within the provisions of the Sherman Act, but which may have the effect of substantially lessening competition within the terms of . . . Section 7 of the Clayton Act." Cf. Brown Shoe Co. v. United States, 370 U.S. 294 (1961); American Tobacco Co. v. United States, 328 U.S. 781, 811 (1946). (2) Because of its "potential" nature, \& 7 entails a lower standard of liability for the same acts that would result in Sherman Act liability if carried to their intended conclusion, thus requiring the plaintiff to show that the potential "threat" of the merger became reality and competition was in fact restrained. See text and notes 33-36 supra. (3) If a successful government $\S 7$ action has preceded the private action and the plaintiff is required to rely on a Sherman Act cause of action he will be unable to use the government judgment as prima facie evidence as provided by $\S 5(a)$ of the Clayton Act. Gottesman v. General Motors Corp., 279 F. Supp. 361 (S.D.N.Y. 1963) (a finding of violation of Clayton $\S 7$ insufficient to support a finding of a Sherman Act violation).

56306 F. Supp. 72 (D. Hawaii 1969).

57 Id. at 88,90 .

58 Text and notes at notes 17-32 supra.

59 Kirihara v. Bendix Corp., 306 F. Supp. 72, 90 (D. Hawaii 1969). 
petitors. This standing restriction would tend to subject only "bad" merged firms to liability since the primary attribute of such firms is their tendency to injure competitors by diminishing the ability of competitors to compete in the relevant market. A successful non-competitor section 4 action would require not only injury to the plaintiff, but potential restraint of competition in the market occupied by the merged firm, as opposed to potential restraint in the non-competitor's own market. Thus in Kirihara, the plaintiff distributor would have had to show potentially lessened competition in the production of oil filters, the market of the manufacturer affected by the challenged horizontal merger.

The factual situation in Daily ${ }^{60}$ and $A m e s^{61}$ may be used to illustrate the effect of the competitor standing requirement. In Ames, plaintiff's competing distributor acquired the defendant, a stapler manufacturer. Because this was a vertical merger, stapler distribution as well as stapler production constituted the relevant market, a market in which the plaintiff distributor was a component. Thus the plaintiff could recover under the Kirihara competitor standard. In Daily, the plaintiff, suing as an employee on the second level away from the market receiving the impact of the allegedly illegal merger, was not a component of the competitive infra-structure of the market. Thus, to recover under the competitor standard, the plaintiff would have had to prove both his own injury and the potentially anticompetitive effect of the merger in the relevant market.

While the above results seem proper in that the plaintiff recovered only where the injury reflected the anticompetitive nature of the challenged merger, this is not the basis on which the competitor requirement denies recovery. Indeed, the difficulty with the competitor requirement is that it would mechanically deny a remedy to some plaintiffs injured by the anticompetitive acts of an illegally merged firm and would effectively immunize from attack some "bad" mergers. ${ }^{62}$ If, for example, the only two competitors in a market merge, no competitors would be left to challenge the merger. The merged firm could then control prices and output and thus injure the consumer, who would be unable to satisfy the competitor requirement. A similar result would occur when a merged firm raises prices and the remaining competitors elect to move under this price umbrella rather than challenge the

60 Daily v. Quality School Plan, Inc., 380 F.2d 484 (5th Cir. 1967).

01 Ames v. Bostitch, Inc., 240 F. Supp. 521 (S.D.N.Y. 1965).

62 The universe of potential plaintiffs is made up of five groups: competitors, who have the remedy; suppliers and distributors (and people in their position such as franchisors), who have a remedy only if they are suing in the position of a competitor; employees and consumers, who would be without a remedy under this competitor formulation. 
merger. ${ }^{63}$ Thus, because of its mechanical nature and its failure to comport closely with the policy of the statute, ${ }^{64}$ limiting $\S 4-\S 7$ actions to competitors is unsatisfactory.

2. The Validation Requirement. The second requirement in Kirihara, that the injury "validate" the probability that the challenged acquisition will be anticompetitive, is a rational means of limiting recovery in $\S 4-\S 7$ actions. This is a specialized standing test that incorporates the policy goals of section 7 into the treble damage action. It seeks to assure that only the anticompetitive acts of illegally merged firms result in treble damage liability, and, if utilized properly, it eliminates the need for inflexible limitations such as the competitor standing requirement.

To satisfy the validation requirement, the injury need not by itself prove that the challenged merger violates section 7 , but it must corroborate the existence of a violation. For instance, a price rise following the merger of two retail store chains would tend to corroborate the existence of a section 7 violation. Thus, if a section 7 violation is proved by additional evidence, consumers should be allowed to recover. Bailey's Bakery, Ltd. v. Continental Baking Co ${ }^{65}$ presents another example of a situation satisfying the validation requirement. Continental, a national baking firm, acquired Love Bakery, a Hawaiian firm, and gained control of 83 per cent of the Hawaiian bread market. Immediately after the merger Continental introduced "Wonder" bread, not previously marketed by Love, in direct competition with plaintiff's sandwich loaf. If Continental's post-merger dominance of the Hawaiian bread market establishes a section 7 violation, plaintiff's subsequent injury in the form of lost sales would corroborate the anticompetitive nature of the merger.

In Ricchetti $v$. Meister Brau, Inc., ${ }^{66}$ on the other hand, a private section 7 suit for injunctive relief under section 16 of the Clayton Act $^{67}$ was dismissed because the plaintiff failed to meet a requirement similar to the validation standard advocated above. ${ }^{68}$ Ricchetti was a distributor of Burgermeister beer before it was acquired by Meister Brau. Shortly

63 Arguably such activity would be remedied by government actions enforcing $\S 7$ in the public interest, but this is an imperfect alternative.

64 Any requirement approaching the mechanical competitor standing requirement would be counter to the trend of Supreme Court cases which attempt to guard against the denial of a remedy by such non-rational means. See cases cited notes 29-31 supra.

65235 F. Supp. 705 (D. Hawaii 1964) (not reaching the question of the scope of the $\S 4-\S 7$ action because court denied the right to have such an action as a matter of law).

66431 F.2d 1211 (9th Cir. 1970).

6715 U.S.C. $\$ 26$ (1964).

68 Ricchetti v. Meister Brau, Inc., 431 F.2d 1211, 1215 (9th Cir. 1970): "Termination of a distributorship does not become a violation of $\$ 7$ simply because the manufacturer or 
after the acquisition his distributorship was terminated and reassigned to Meister Brau distributors. The loss of plaintiff's distribution account did not of itself validate any potential restraint on competition, since his termination was probably a business decision based on efficiency criteria. Thus he was properly denied standing to challenge the legality of the merger under section 7 .

The validation standard is desirable for the same reasons that the overbroad Daily standard was rejected. ${ }^{69}$ First, requiring the plaintiff's injury to validate an injury to competition facilitates the determination of whether a challenged merger is in fact illegal. Second, the validation requirement helps assure that only the anticompetitive acts of illegally merged firms result in $\$ 4$ liability. Injuries not validating the anticompetitive nature of the merger are probably economically justified and not intended to be prevented by section 7 . Third, the validation requirement lessens the possibility that the pecuniary motivation of private plaintiffs and the punitive, treble damage nature of section 4 will result in deterrent overkill of beneficial mergers.

By penalizing the anticompetitive acts of illegally merged firms and shielding firms formed by beneficial mergers from liability, the validation requirement utilizes the motivations of the treble damage plaintiffs to effectuate the proper enforcement policy of section 7. This is not to say that the validation requirement might not be appropriate in other forms of treble damage actions, but only that, because of the special characteristics of $\S 4-\S 7$ actions, it is an especially useful tool in formulating a consistent and advantageous policy of enforcement under section 7.

supplier taking such action has recently been involved in a merger or acquisition of stock or assets with another company. ... There must be a further showing that, as a result of the past merger acts, the merger has an effect on commerce which is proscribed within the meaning of all elements of Section 7."

69 Text and notes at notes 39-52 supra. 